\title{
The Role of Chemokines in Alzheimer's Disease
}

\author{
Adrian Jorda ${ }^{1}$, Juan Campos-Campos ${ }^{1}$, Antonio Iradi $^{2}$, Martin Aldasoro ${ }^{2}$, Constanza Aldasoro ${ }^{2}$, \\ Jose M. Vila ${ }^{2}$ and Soraya L. Valles ${ }^{2, *}$
}

${ }^{I}$ Department of Nursing, Faculty of Nursing and Podiatry, University of Valencia, Valencia, Spain; ${ }^{2}$ Department of Physiology, Faculty of Medicine, University of Valencia, Valencia, Spain

\begin{abstract}
Objective: The most common multifactorial neurodegenerative disorder occurring in old age is Alzheimer's disease. The neuropathological hallmarks of that disorder are amyloid plaques with the presence of $\beta$-amyloid aggregates, intraneuronal tau protein tangles, and chronic inflammation. Brain cells such as microglia and astrocytes are inflammatory cells associated with Alzheimer's disease and involved in the production of inflammatory mediators, such as cytokines and chemokines. Chemokines consist of a large family of protein mediators with low molecular weight, which able to control the migration and residence of all immune cells. In pathological conditions, such as Alzheimer's disease, chemokines contribute to the inflammatory response by recruiting $\mathrm{T}$ cells and controlling microglia/macrophages activation.
\end{abstract}

ART I C L E H I S T ORY

Received: October 23, 2019 Revised: November 22, 2019 Accepted: December 04, 2019

DOI: 10.2174/1871530320666200131110744

Methods: The present study focuses on the role that chemokines and their receptors play in Alzheimer's disease and in processes such as inflammation and oxidative stress.

Results: Chemokines are important mediators in $\mathrm{AD}$ and inflammation. They promote $\mathrm{A} \beta$ deposition and TAU hyperphosphorylation aggravating and increasing the progression of AD. Moreover, they affect the processing of senile plaques and produce abnormal TAU phosphorylation.

Conclusion: There is no cure for AD but the therapeutic potential of chemokines to control the development of the disease may be a field of study to consider in the future.

Keywords: Alzheimer's disease, amyloid precursor protein, $\beta$-amyloid, chemokines, chemokine receptors, inflammation.

\section{INTRODUCTION}

Alzheimer's disease (AD) is the most common multifactorial neurodegenerative disorder, within old age. The disorder consists mainly of progressive and irreversible deterioration in mental functions, such as cognition and memory, progressing to remote memory impairment as the disorder progresses. The neuropathological hallmarks of AD are amyloid plaques with $\beta$-amyloid depositions and intraneuronal hyperphosphorylated amyloid precursor protein (APP) tangles [1, $2]$. The distribution of $\beta$-amyloid depositions is located throughout the brain, most specifically, in the cerebral cortex and in the hippocampus of AD patients [3].

A neuropathological process to consider in $\mathrm{AD}$ is inflammation. The cells involved in this process are neurons, astrocytes, and microglia which, when stimulated, produce inflammatory mediators [4, 5]. Microglia and astrocytes normally react to disease stress to resolve pathological states. However, in chronic neurodegenerative diseases, microglia and astrocytes can change the phenotype, with subsequent alteration in their helpful functions. These cells can

*Address correspondence to this author at the Department of Physiology, Faculty of Medicine, University of Valencia, Valencia, Spain;

E-mail: lilian.valles@uv.es sometimes release reactive oxygen species (ROS), reactive nitrogen species (RNS), chemokines, and cytokines [6, 7] and are known as reactive glial cells which can promote neuronal death. These cells use gene expression and glial scar formation mechanisms to promote functional changes, which can be either beneficial [8] or detrimental [9] to cells. A colocalization of neurofibrillary tangles and amyloid- $\beta$ with reactive glial cells have been detected in animal models and in brains of $\mathrm{AD}$ patients $[10,11]$.

This review focuses on the role that chemokines play in Alzheimer's disease.

\section{MATERIAL AND METHODS}

This review focuses on the most recent studies on the implication of chemokines and their cellular receptors in Alzheimer's disease and underlying processes, such as inflammation and oxidative stress. In this sense, the physiopathological role of chemokines in relation to amyloid plaques development and TAU hyperphosphorylation was analyzed. The research for the most relevant studies in the field was carried out by consulting MEDLINE (1991-2019) and EMBASE (1991-2019). 


\section{CHEMOKINES. RESULTS AND DISCUSSION}

Chemokines are small heparin-binding proteins that generally have a low molecular weight from 7 to $15 \mathrm{kDa}$. This family of proteins is divided into four subcategories, depending on the number of amino acids separating two cysteine residues, therefore: $\alpha(\mathrm{CXC}), \beta(\mathrm{CC}), \gamma(\mathrm{CX} 3 \mathrm{C})$, and $\delta(\mathrm{C})$ $[12,13]$. Chemokines carry out their function through chemokine receptors from a superfamily of G-proteincoupled receptors and are classified in the same manner. Many Chemokines bind to more than one receptor and many receptors conjugate to various Chemokines. Immune cells and cells from the nervous system such as microglia, astrocytes, oligodendrocytes, Schwann cells, endothelial cells, and neurons can release chemokines after being stimulated by pathogens or unregular cells [14] (Ramesh et al., 2013). Regarding receptors, specifically, neurons express CXCR2, CXCR3, and CXCR4, microglia express CCR2, CCR5, and CX3CR1, and astrocytes express CXCR2, CXCR4, CCR1, CCR2, CCR3, CCR5, CCR10, CCR11, and CX3CR1 [13]. Chemokines and their receptors are able to control the migration and the residence of all immune cells. Some of them are considered pro-inflammatory and can induce immune response at the site of infection, and others are considered homeostatic, controlling cell migration during development and the maintenance of the tissue (Table 1) $[15,16]$.

\subsection{CCL1 and its Receptor CCR8}

CCL1 is the ligand of CCR8 that encodes a member of the $\beta$-chemokine receptor family [17]. A decrease in CCL1 expression and an increased expression of CCR8 in APP/PS1 mice compared to Wild type mice has been demonstrated [7], indicating a rise in receptor expression to supply downregulation of its chemokine. CCR8 is expressed in neurons, microglia, and astrocytes [18] and is furtherly controlled by skin-specific factors. Furthermore, CCR8 accumulates microglial cells in the CNS of APP/PS1 mice [18], promoting chemotaxis of mononuclear cells and phagocytosis. Inflammation occurred during Alzheimer's disease produced high liberation of cytokines and chemokines, which accelerated the inflammatory cascade [19]. Stimulation of primary microglial cultures by lipopolysaccharides diminished the expression of CCL1 in a mouse model of diabetic neuropathy [20] and CCL1/CCR8 cross-talk promoted the development of inflammation in AD with decreases in CCL1 expression [7]. Regarding microglial phagocytosis: CCL1 eliminated neurotoxic molecules, debris, or microbes [21]. A decrease in CCL1 production may explain the decline in phagocytic elimination of $\mathrm{A} \beta$ detected in $\mathrm{AD}$ [22]. Furthermore, in Taiep rats, an accumulation of microglial cells in the CNS, with a subsequent increase in chemotaxis and phagocytosis, was detected, with an upregulation in CCR8 expression (mRNA and protein) [23].

\subsection{CCL3, CCL4, CCL5 and its Receptor CCR5}

Macrophages, monocytes, astrocytes, microglia, epithelium, endothelium, vascular smooth muscle, fibroblasts, and memory-associated neurons express CCL3, CCL4, CCL5, and its receptor CCR5 [24]. In addition to the modulation of the immune response, CCR5 could influence neuronal sur- vival whilst being involved in neuroprotective mechanisms [25]. A downregulation of CCR5 was detected in APP/PS1 mice with the upregulation of CCL3 and CCL4 [7]. The increase in chemokines could lead to a decrease in the expression of the receptor, and, at the same time, the decrease in the CCR5 receptor could lead to an increase in the expression of their chemokines, but this point should be studied in the future research. Neuronal survival can be influenced by CCR5 and could be involved in neuroprotective mechanisms [26]. In CCR5-/- mice, a greater number of reactive astrocytes was detected in comparison with $\mathrm{CCR} 5+/+$ mice, indicating that the absence of CCR5 leads to astrocyte activation [27]. Furthermore, cell death in CCR5-/- mice brains are significantly higher than in CCR5+/+ mice [27]. Furthermore, CCR5 elimination could be involved in inadequate development and maturation of dopaminergic neurons and in the prevention of macrophage infiltration and demyelination $[28,29]$.

LPS injection significantly induced astrogliosis, $A \beta$ deposition, and $\beta$-secretase expression in CCR5 knockout mice, compared with CCR5 wild type mice [30]. In addition, an increase in impaired memory and in $A \beta$ deposits could explain the cell death that takes place in AD patients.

Regarding CCR5 chemokines, high levels of CCL3 in peripheral $\mathrm{T}$ lymphocytes have been found in $\mathrm{AD}$ patients, as compared to healthy patients [31]. In addition, an increase in CCL3 expression in 7-month-old APP/PS1 mice cortex was detected [7]. CCL3 is likely to contribute to the pathogenesis of $\mathrm{AD}$ since an increase of that chemokine has been observed, alongside an accumulation of lymphocytes, monocytes, and glial cells in a hypoxic mouse model [32]. CCL3 is found in higher concentrations in microglia, astrocytes, and perivascular macrophages in Alzheimer's disease [33, 34], and involved in cellular infiltration via leucocyte recruitment. Cognitive impairment caused by TAU protein accumulation could likely be promoted by CCL 3 cell infiltration in the brain [35]. CCL4 expression is higher in APP/PS1 mice as compared to wild type mice along with an increase in $A \beta$ deposition $[36,7]$ which also occurs with a common location of CCL4, A $\beta$, and astrocytes in this mice. Astrocytes from AD produce a $\beta$-secretase enzyme that binds to amyloid precursor protein (APP) increasing A $\beta$ production [37]. This data indicates that an acceleration in $A \beta$ deposition leads to a likely deterioration in memory functions [38]. Furthermore, an increase in $A \beta_{1-42}$ deposition in the brains of those mice bearers of a mutation in Toll-like receptor 4 was associated with a decrease in CCL3 and CCL4 expression, by thus ameliorating cognitive functions in these mice. Therefore, in the neurotoxicity mediated by $A \beta$, the reduction of $A \beta$ deposits and preservation of cognitive functions were carried out in microglia by TLR4 signaling [39].

CCL5 appears on endothelial cells, glia, and neurons. Treatment with CCL5 increases neuronal survival and diminishes cell death produced by the toxic peptide $\mathrm{A} \beta[40,41]$. In vivo studies demonstrated no changes in CCL5 expression in APP/PS1 compared with wild type mice [7]. On the contrary, other authors demonstrated an increase in CCL5 expression in transgenic mice brain and in AD human brain [41, 42, 43]. After all these data, CCL5 function and its mechanisms remain unclear and yet to be established. 
Table 1. Effects of the chemokines and the chemokine receptors.

\begin{tabular}{|c|c|c|c|}
\hline Chemokine Receptor & Chemokines & & References \\
\hline \multirow[t]{5}{*}{ CCR8 } & & Accumulation of microglial cells & {$[18]$} \\
\hline & & Increase in inflammation and chemokines & {$[18,19,23]$} \\
\hline & Decrease in CCL1 & Decrease elimination of $A \beta$ & {$[22]$} \\
\hline & & Decrease elimination of debris & {$[21]$} \\
\hline & & Decrease elimination of neurotoxic molecules & [21] \\
\hline CCR5 & & Involve in neuronal survival and neuroprotective mechanisms & [25] \\
\hline \multirow[t]{8}{*}{ Elimination of CCR5 } & & Activation of astrocytes and neuronal cell death & {$[27]$} \\
\hline & & Decrease development and maturation of neurons & {$[28,29]$} \\
\hline & Increase of CCL3 & Increase lymphocytes, monocytes and glial cells & {$[32]$} \\
\hline & & CCL3 increase in $\mathrm{AD}$ & {$[33,34]$} \\
\hline & Increase of CCL4 & Appear in APP/PS1 & {$[36,7]$} \\
\hline & & Increase $A \beta$ deposition & {$[36,7]$} \\
\hline & Treatment with CCL5 & Increase neuronal survival & {$[40,41]$} \\
\hline & & Decrease cell death & {$[40,41]$} \\
\hline \multirow[t]{6}{*}{ Decrease of CCR2 } & & Increase in disease progression in $\mathrm{AD}$ & {$[54,55]$} \\
\hline & & Increase amyloid pathology & {$[54,55]$} \\
\hline & Increase of CCL2 & Increased in $\mathrm{AD}$ & {$[46,47]$} \\
\hline & & Decrease cognitive state & {$[50,51,52]$} \\
\hline & & Increase disease progression & {$[50,51,52]$} \\
\hline & & Increase inflammation & [44] \\
\hline \multirow[t]{6}{*}{ Deletion of CXCR3 } & & Produce $A \beta$ decrease & {$[61]$} \\
\hline & & Produce inflammation decrease & {$[61,59]$} \\
\hline & & Rescue the behavioural deficits & {$[61]$} \\
\hline & & Increase detected in $\mathrm{AD}$ astrocytes & {$[56]$} \\
\hline & & Located with $A \beta$ in mild $A D$ patients & {$[57,58]$} \\
\hline & & Increase inflammation & {$[59]$} \\
\hline \multirow[t]{7}{*}{ CX3CR1 deficiency } & & Increase TAU pathology & [69] \\
\hline & & Increase inflammatory mediators & {$[63,67]$} \\
\hline & & Increase neural death & {$[67]$} \\
\hline & CX3CL1 & Increased in brain and plasma of AD patients & {$[65]$} \\
\hline & & Increase microglial activation & {$[62,63]$} \\
\hline & & Increase cytokines production & {$[63]$} \\
\hline & & Increased cognitive decline & {$[66]$} \\
\hline \multirow[t]{2}{*}{ CXCR2 } & & High levels in AD & {$[70,71]$} \\
\hline & & Role in cognitive functions & [72] \\
\hline
\end{tabular}




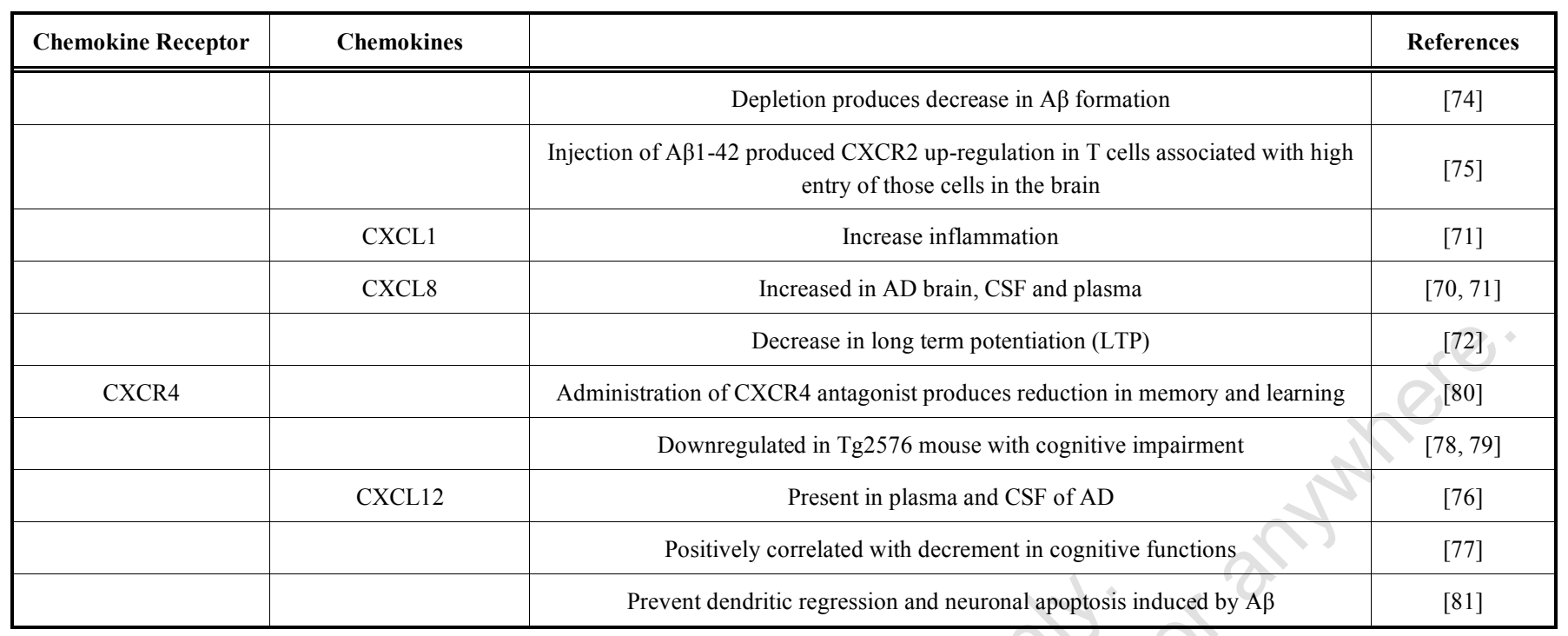

\subsection{CCL2 and its Receptor CCR2}

Data the literature suggest a crucial role for CCL2-CCR2 signalling in Alzheimer's disease. Microglia and astrocytes mostly produce CCL2 [44]. Clinical data of AD patients report no association between CCL2 plasma levels and AD [45]. On the other hand, most authors provided evidence of a detrimental role in $\mathrm{AD}$ pathogenesis with overexpression of CCL2 in the brain [46, 47], in microglia, microvessels, and in mature senile plaques [48]. Furthermore, CCL2 expression in the cerebrospinal fluid (CSF) and the brain is a good predictor of AD strictness $[46,49]$ and moreover, the CCL2 increase correlates directly with cognitive decline and the disease progression $[50,51,52]$. Overexpression of APP and CCL2 did not produce alterations in APP processing. Nevertheless, increases in $A \beta$ levels ended up in their aggregation and deposition in APP/CCL2 mice [53]. CCL2 receptor (CCR2) was the first chemokine receptor associated with AD. Decreases in CR2 contribute to disease progression and amyloid pathology, such as in Tg2576 and APP/PS1 mice $[54,55]$. These authors indicate that the progression of the disease could be due to a decrease in the accumulation of microglia, elimination of $A \beta$ all led by a reduction in macrophage recruitment. Moreover, CCL2/CCR2 is involved in inflammation due to its capability to trigger inflammatory mediators that carry out the inflammation cascade, thus initiating the entire inflammatory process.

\subsection{CXCL10 and its Receptor CXCR3}

CXCL10 is primarily and mainly expressed in astrocytes transgenic mice bearers of $\mathrm{AD}$ [56], where it is located alongside $\mathrm{A} \beta[57,58]$ and in $\mathrm{CSF}$ of mild $\mathrm{AD}$ patients [59]. Furthermore, CXCL10 is involved in inflammatory processes because LPS injection increases CXCL10 in the rat brains and in cultured astrocytes and microglia [60]. In APP/PS1 mice models, CXCR3-deficiency, produced by the deletion of CXCR3, reduced significantly the $\mathrm{A} \beta$ toxic peptide and the plaque formation in the brain. Furthermore, microglial activation took place, indicating the existence of its recruitment in the plaque borders [61]. In addition, CXCR3- deficiency enhanced behavioral alterations and decreased neural inflammation. On the contrary, in tau pathology, the role of CX3CR1 remained uncertain.

\subsection{CX3CL1 and its Receptor CX3CR1}

$\mathrm{CX} 3 \mathrm{CL} 1$ is a transmembranous protein produced by neurons and astrocytes and its receptor CX3CR1 is expressed constitutively in microglia and, partially, in astrocytes and neurons $[62,63]$. In this way, neurons can regulate microglial activation via CXC3CL1/CX3CR1 pathways [64]. These mechanisms control growth factor genesis, cytokines production (IL-1 $\beta$ ) [63], microglial phagocytosis, and progenitor cells' activity [64]. In patients with mild $A D$, CX3CL1 serological concentrations are increased and their posterior decline is directly correlated with cognitive deterioration [65]. On the other hand, in the hippocampus of $\mathrm{AD}$ patients, a CX3CL1 overexpression was detected [66]. In AD mouse models, changes in CX3CL1/CX3CR1 can be both neuroprotective and neurotoxic. In APP/PS1, R1.40, and CRND8 mouse models, a deficit in CX3CR1 meant a reduction in amyloid deposits and, thereby, an increase in microglial $A \beta$ phagocytic capacity $[63,67]$, both associated with a decrease in TNF levels and an increase in IL- $1 \beta$ levels. Furthermore, in rats injected with $A \beta_{1-40}$ an upregulation of CX3CR1 occurred with microglial activation and an ulterior increase in cognitive impairment [68]. On the other hand, in mice expressing human APP, CX3CL1 deficiency meant an increase in tau pathology, expression of proinflammatory mediators, and neural death all affecting negatively both cognition and memory as a final effect [69].

\subsection{CXCL1, CXCL8 and its Receptor CXCR2}

CXCL1 and CXCL8 are ligands of CXCR2. They are expressed in neurons, astrocytes, and microglia as one of the final products following pro-inflammatory signals. CXCL1 is furtherly expressed in immune and CNS cells. In $\mathrm{AD}$ CXCL8 is increased in CSF, serum, and brain [70, 71]. Experiments with hippocampal slices, CXCL8 inhibits LTP which is reversed after incubation with CXCR2 demonstrat- 


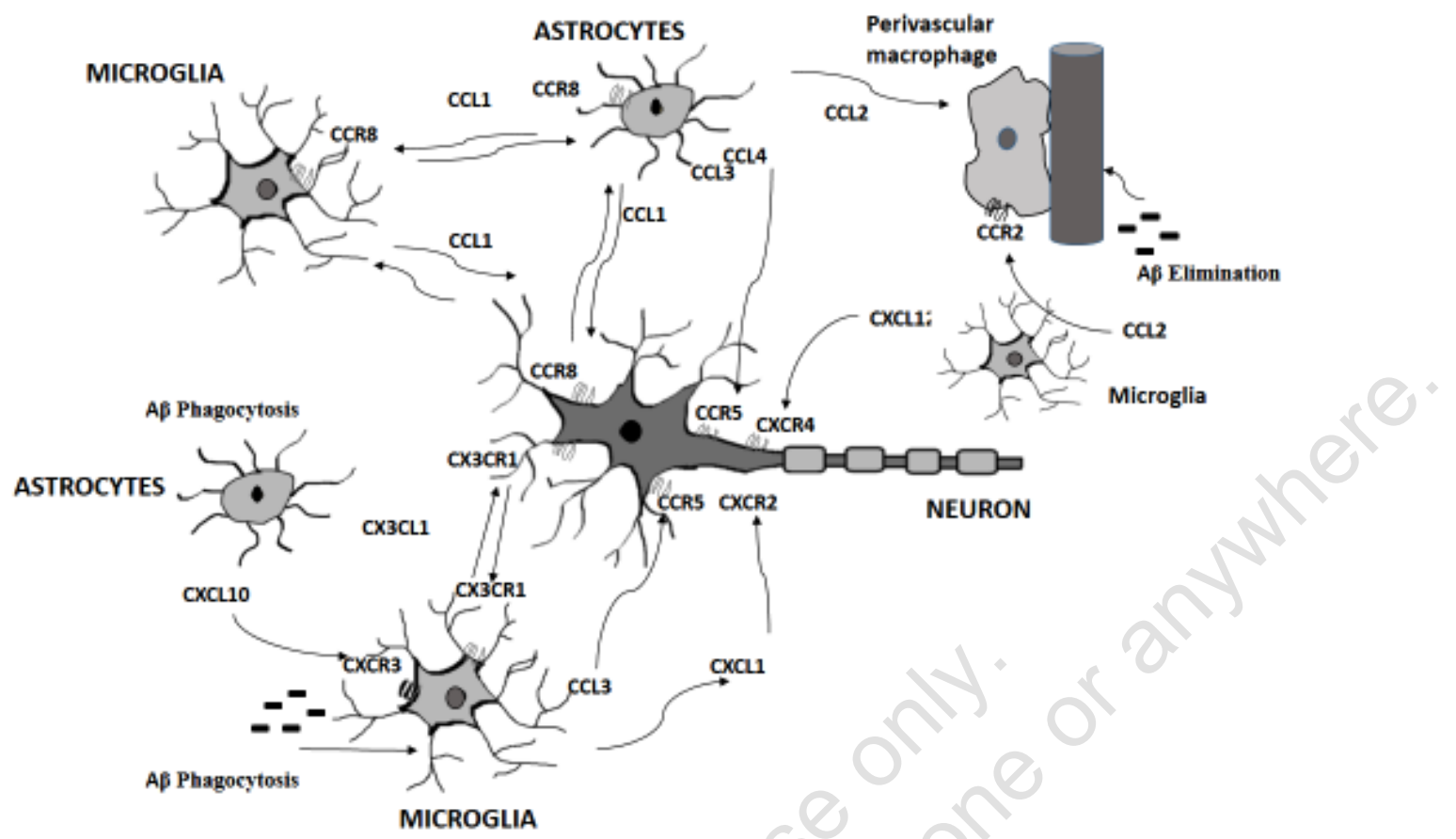

Fig. (1). (A higher resolution / colour version of this figure is available in the electronic copy of the article).

ing a role in cognitive functions [72]. Furthermore, high levels of CXCR2 in microglia and astrocytes in AD bearers were detected [73]. Knockdown or depletion of CXCR2 antagonists (SB2250002) decreased $A \beta 1-42$ and $A \beta 1-40$ expression and the accumulation of $\gamma$-secretase elements. On the other hand, an increase of $\mathrm{A} \beta_{1-40}$ production was detected after treatment with agonists [74]. Moreover, injection of A $\beta 1-42$ produced CXCR2 up-regulation in T cells associated with the high entry of those cells in the brain [75]. CXCR2 is involved in cognitive dysfunction in $\mathrm{AD}$, by increasing $\mathrm{T}$ cell recruitment via $A \beta$ induction and liberation following an increased expression of $\gamma$-secretase complex.

\subsection{CXCL12 and its Receptor CXCR4}

CNS express both of them [76]. They regulate neuronal excitability and synaptic transmission. In patients with early $\mathrm{AD}, \mathrm{CXCL} 12$ is present in plasma and CSF and inversely correlated with the levels of tau protein in CSF. Furthermore, these chemokines and their receptors showed a direct relation with cognitive function detriment [77]. In animal models of $\mathrm{AD}$, the CXCR4 receptor and CXCL12 are downregulated in Tg2576 mouse with cognitive impairment [78, 79]. Moreover, the administration of CXCR4 antagonist brought upon memory and cognitive reduction in young, non-transgenic mice, showing that low levels of CXCL12/CXCR4 produced cognitive deficits [80]. In addition, CXCL12 inhibited the effects of A $\beta$ toxic peptide possibly by the prevention of dendritic destruction and apoptosis occasioned by $\mathrm{A} \beta$ [81]. CXCL2 produced neuroprotection and anti-amyloidogenic actions in 5xFAD mice treated painlessly with hNGFp [82].

\section{CONCLUSIONS}

This review summarizes the role of chemokines and their receptors as important mediators in $\mathrm{AD}$ and inflammation.
They promote $A \beta$ deposition and TAU hyperphosphorylation aggravating and increasing the progression of $\mathrm{AD}$. There remains, though, a long road to clarify and fully understand the specific actions of chemokines in the inflammatory processes in AD. Pharmacotherapy may have a promising future in detaining or decelerating the development of this neurodegenerative disease (Fig. 1).

\section{LIST OF ABBREVIATIONS}

$\begin{array}{ll}\mathrm{AD} & =\text { Alzheimer's Disease } \\ \mathrm{ROS} & =\text { Reactive Oxygen Species } \\ \mathrm{APP} / \mathrm{PS} 1 & =\text { Amyloid Precursor Protein/Presenilin 1 } \\ \mathrm{LPS} & =\text { Lipopolysaccharides } \\ \mathrm{TLR} & =\text { Interleukin } \\ \mathrm{IL} & =\text { Cerebrospinal Fluid } \\ \mathrm{CSF} & =\text { Amyloid } \beta \\ \mathrm{A} \beta & =\text {-C Chemokine Receptor type } \\ \mathrm{CCR} & =\text { C-X-C Chemokine Receptor type } \\ \mathrm{CXCR} & =\text { Chemokine (C-C motif) Ligand } \\ \mathrm{CCL} & =\text { C-X-C Motif Chemokine Ligand } \\ \mathrm{CXCL} & =\text { Central Nervous system }\end{array}$

\section{AUTHOR CONTRIBUTIONS}

All authors made substantive intellectual contributions to the present study and approved the final manuscript. A.J. drafted and revised the manuscript and collected the bibliography. J.C.C. drafted and revised the manuscript. A.I. pro- 
vided technical assistance conducting to the preparation of the paper. M.A. revised the manuscript. C.A. checked English. J.M.V. revised the manuscript. S.L.V. designed the manuscript; draft revised the manuscript; and chose the bibliography.

\section{CONSENT FOR PUBLICATION}

Not applicable.

\section{FUNDING}

None.

\section{CONFLICT OF INTEREST}

The authors declare no conflict of interest, financial or otherwise.

\section{ACKNOWLEDGEMENTS}

We want to thank the collaboration of the secretaries and laboratory technicians of the Department of Physiology, University of Valencia.

\section{REFERENCES}

[1] Selkoe, D.J. Alzheimer's disease: genes, proteins, and therapy. Physiol. Rev., 2001, 81(2), 741-766. http://dx.doi.org/10.1152/physrev.2001.81.2.741 PMID: 11274343

[2] Huang, Y.; Mucke, L. Alzheimer mechanisms and therapeutic strategies. Cell, 2012, 148(6), 1204-1222. http://dx.doi.org/10.1016/j.cell.2012.02.040 PMID: 22424230

[3] Braak, H.; Braak, E. Neuropathological stageing of Alzheimer-related changes. Acta Neuropathol., 1991, 82(4), 239-259. http://dx.doi.org/10.1007/BF00308809 PMID: 1759558

[4] Tuppo, E.E.; Arias, H.R. The role of inflammation in Alzheimer's disease. Int. J. Biochem. Cell Biol., 2005, 37(2), 289-305. http://dx.doi.org/10.1016/j.biocel.2004.07.009 PMID: 15474976

[5] Heneka, M.T.; O’Banion, M.K.; Terwel, D.; Kummer, M.P. Neuroinflammatory processes in Alzheimer's disease. J. Neural Transm. (Vienna), 2010, 117(8), 919-947. http://dx.doi.org/10.1007/s00702-010-0438-z PMID: 20632195

[6] Valles, S.L.; Dolz-Gaiton, P.; Gambini, J.; Borras, C.; Lloret, A.; Pallardo, F.V.; Viña, J. Estradiol or genistein prevent Alzheimer's disease-associated inflammation correlating with an increase PPAR gamma expression in cultured astrocytes. Brain Res., 2010, 1312, 138144. http://dx.doi.org/10.1016/j.brainres.2009.11.044 PMID: 19948157

[7] Jorda, A.; Cauli, O.; Santonja, J.M.; Aldasoro, M.; Aldasoro, C.; Obrador, E.; Vila, J.M.; Mauricio, M.D.; Iradi, A.; Guerra-Ojeda, S.; Marchio, P.; Valles, S.L. Changes in chemokines and chemokine receptors expression in a mouse model of Alzheimer's disease. Int. J. Biol. Sci., 2019, 15(2), 453-463. http://dx.doi.org/10.7150/ijbs.26703 PMID: 30745834

[8] Anderson, M.A.; Ao, Y.; Sofroniew, M.V. Heterogeneity of reactive astrocytes. Neurosci. Lett., 2014, 565, 23-29. http://dx.doi.org/10.1016/j.neulet.2013.12.030 PMID: 24361547

[9] Liddelow, S.A.; Guttenplan, K.A.; Clarke, L.E.; Bennett, F.C.; Bohlen, C.J.; Schirmer, L.; Bennett, M.L.; Münch, A.E.; Chung, W.S.; Peterson, T.C.; Wilton, D.K.; Frouin, A.; Napier, B.A.; Panicker, N.; Kumar, M.; Buckwalter, M.S.; Rowitch, D.H.; Dawson, V.L.; Dawson, T.M.; Stevens, B.; Barres, B.A. Neurotoxic reactive astrocytes are induced by activated microglia. Nature, 2017, 541(7638), 481-487. http://dx.doi.org/10.1038/nature21029 PMID: 28099414

[10] Hickman, S.E.; Allison, E.K.; El Khoury, J. Microglial dysfunction and defective beta-amyloid clearance pathways in aging Alzheimer's disease mice. J. Neurosci., 2008, 28(33), 8354-8360.
http://dx.doi.org/10.1523/JNEUROSCI.0616-08.2008 PMID: 18701698

[11] López-González, I.; Schlüter, A.; Aso, E.; Garcia-Esparcia, P.; Ansoleaga, B.; LLorens, F.; Carmona, M.; Moreno, J.; Fuso, A.; PorteroOtin, M.; Pamplona, R.; Pujol, A.; Ferrer, I. Neuroinflammatory signals in Alzheimer disease and APP/PS1 transgenic mice: correlations with plaques, tangles, and oligomeric species. J. Neuropathol. Exp. Neurol., 2015, 74(4), 319-344.

http://dx.doi.org/10.1097/NEN.0000000000000176 PMID: 25756590

[12] Liu, C.; Cui, G.; Zhu, M.; Kang, X.; Guo, H. Neuroinflammation in Alzheimer's disease: chemokines produced by astrocytes and chemokine receptors. Int. J. Clin. Exp. Pathol., 2014, 7(12), 83428355. PMID: 25674199

[13] Horuk, R. Chemokine receptors. Cytokine Growth Factor Rev., 2001 12(4), 313-335 http://dx.doi.org/10.1016/S1359-6101(01)00014-4 PMID: 11544102

[14] Ramesh, G.; MacLean, A.G.; Philipp, M.T. Cytokines and chemokines at the crossroads of neuroinflammation, neurodegeneration, and neuropathic pain. Mediators Inflamm., 2013, 2013480739 http://dx.doi.org/10.1155/2013/480739 PMID: 23997430

[15] Djukic, M.; Mildner, A.; Schmidt, H.; Czesnik, D.; Brück, W.; Priller, J.; Nau, R.; Prinz, M. Circulating monocytes engraft in the brain, differentiate into microglia and contribute to the pathology following meningitis in mice. Brain, 2006, 129(Pt 9), 2394-2403.

http://dx.doi.org/10.1093/brain/awl206 PMID: 16891321

[16] Palomino, D.C.; Marti, L.C. Chemokines and immunity. Einstein (Sao Paulo), 2015, 13(3), 469-473. http://dx.doi.org/10.1590/S1679-45082015RB3438 PMID: 26466066

[17] Garlisi, C.G.; Xiao, H.; Tian, F.; Hedrick, J.A.; Billah, M.M.; Egan, R.W.; Umland, S.P. The assignment of chemokine-chemokine receptor pairs: TARC and MIP-1 beta are not ligands for human CCchemokine receptor 8. Eur. J. Immunol., 1999, 29(10), 3210-3215. http://dx.doi.org/10.1002/(SICI)1521-4141(199910)29:10<3210::AIDIMMU3210>3.0.CO;2-W PMID: 10540332

[18] Akimoto, N.; Ifuku, M.; Mori, Y.; Noda, M. Effects of chemokine (C$\mathrm{C}$ motif) ligand 1 on microglial function. Biochem. Biophys. Res. Commun., 2013, 436(3), 455-461.

http://dx.doi.org/10.1016/j.bbrc.2013.05.126 PMID: 23747724

[19] Gorelick, P.B. Role of inflammation in cognitive impairment: results of observational epidemiological studies and clinical trials. Ann. N. Y. Acad. Sci., 2010, 1207, 155-162.

http://dx.doi.org/10.1111/j.1749-6632.2010.05726.x PMID: 20955439

[20] Zychowska, M.; Rojewska, E.; Piotrowska, A.; Kreiner, G.; Nalepa, I.; Mika, J. Spinal CCL1/CCR8 signaling interplay as a potential therapeutic target - Evidence from a mouse diabetic neuropathy model. Int. Immunopharmacol., 2017, 52, 261-271. http://dx.doi.org/10.1016/j.intimp.2017.09.021 PMID: 28961489

[21] Trebst, C.; Staugaitis, S.M.; Kivisäkk, P.; Mahad, D.; Cathcart, M.K.; Tucky, B.; Wei, T.; Rani, M.R.; Horuk, R.; Aldape, K.D.; Pardo, C.A.; Lucchinetti, C.F.; Lassmann, H.; Ransohoff, R.M. CC chemokine receptor 8 in the central nervous system is associated with phagocytic macrophages. Am. J. Pathol., 2003, 162(2), 427-438. http://dx.doi.org/10.1016/S0002-9440(10)63837-0 PMID: 12547701

[22] Takata, K.; Amamiya, T.; Mizoguchi, H.; Kawanishi, S.; Kuroda, E.; Kitamura, R.; Ito, A.; Saito, Y.; Tawa, M.; Nagasawa, T.; Okamoto, H.; Sugino, Y.; Takegami, S.; Kitade, T.; Toda, Y.; Kem, W.R.; Kitamura, Y.; Shimohama, S.; Ashihara, E. Alpha7 nicotinic acetylcholine receptor-specific agonist DMXBA (GTS-21) attenuates $\mathrm{A} \beta$ accumulation through suppression of neuronal $\gamma$-secretase activity and promotion of microglial amyloid- $\beta$ phagocytosis and ameliorates cognitive impairment in a mouse model of Alzheimer's disease. Neurobiol. Aging, 2018, 62, 197-209.

http://dx.doi.org/10.1016/j.neurobiolaging.2017.10.021 PMID: 29175709

[23] Soto-Rodriguez, G.; Gonzalez-Barrios, J.A.; Martinez-Fong, D.; Blanco-Alvarez, V.M.; Eguibar, J.R.; Ugarte, A.; Martinez-Perez, F.; Brambila, E.; Peña, L.M.; Pazos-Salazar, N.G.; Torres-Soto, M.; Garcia-Robles, G.; Tomas-Sanchez, C.; Leon-Chavez, B.A. Analysis of chemokines and receptors expression profile in the myelin mutant taiep rat. Oxid. Med. Cell. Longev., 2015, 2015397310 http://dx.doi.org/10.1155/2015/397310 PMID: 25883747

[24] Corbeau, P.; Reynes, J. CCR5 antagonism in HIV infection: ways, effects, and side effects. AIDS, 2009, 23(15), 1931-1943. 
http://dx.doi.org/10.1097/QAD.0b013e32832e71cd PMID: 19724192

[25] Sorce, S.; Myburgh, R.; Krause, K.H. The chemokine receptor CCR5 in the central nervous system. Prog. Neurobiol., 2011, 93(2), 297-311. http://dx.doi.org/10.1016/j.pneurobio.2010.12.003 PMID: 21163326

[26] Rostène, W.; Kitabgi, P.; Parsadaniantz, S.M. Chemokines: a new class of neuromodulator? Nat. Rev. Neurosci., 2007, 8(11), 895-903. http://dx.doi.org/10.1038/nrn2255 PMID: 17948033

[27] Kaul, M.; Ma, Q.; Medders, K.E.; Desai, M.K.; Lipton, S.A. HIV-1 coreceptors CCR5 and CXCR4 both mediate neuronal cell death but CCR5 paradoxically can also contribute to protection. Cell Death Differ., 2007, 14(2), 296-305. http://dx.doi.org/10.1038/sj.cdd.4402006 PMID: 16841089

[28] Glass, W.G.; Liu, M.T.; Kuziel, W.A.; Lane, T.E. Reduced macrophage infiltration and demyelination in mice lacking the chemokine receptor CCR5 following infection with a neurotropic coronavirus. $\mathrm{Vi}$ rology, 2001, 288(1), 8-17. http://dx.doi.org/10.1006/viro.2001.1050 PMID: 11543653

[29] Choi, D.Y.; Lee, M.K.; Hong, J.T. Lack of CCR5 modifies glial phenotypes and population of the nigral dopaminergic neurons, but not MPTP-induced dopaminergic neurodegeneration. Neurobiol. Dis., 2013, 49, 159-168. http://dx.doi.org/10.1016/j.nbd.2012.08.001 PMID: 22922220

[30] Hwang, C.J.; Park, M.H.; Hwang, J.Y.; Kim, J.H.; Yun, N.Y.; Oh, S.Y.; Song, J.K.; Seo, H.O.; Kim, Y.B.; Hwang, D.Y.; Oh, K.W.; Han, S.B.; Hong, J.T. CCR5 deficiency accelerates lipopolysaccharideinduced astrogliosis, amyloid-beta deposit and impaired memory function. Oncotarget, 2016, 7(11), 11984-11999. http://dx.doi.org/10.18632/oncotarget.7453 PMID: 26910914

[31] Man, S.M.; Ma, Y.R.; Shang, D.S.; Zhao, W.D.; Li, B.; Guo, D.W.; Fang, W.G.; Zhu, L.; Chen, Y.H. Peripheral T cells overexpress MIP1alpha to enhance its transendothelial migration in Alzheimer's disease. Neurobiol. Aging, 2007, 28(4), 485-496. http://dx.doi.org/10.1016/j.neurobiolaging.2006.02.013 PMID 16600437

[32] Zhang, F.; Zhong, R.; Li, S.; Fu, Z.; Cheng, C.; Cai, H.; Le, W. Acute hypoxia induced an imbalanced M1/M2 activation of microglia through NF-Kb signalling in Alzheimer's disease mice and wild-type littermates. Front. Aging Neurosci., 2017, 9, 282. http://dx.doi.org/10.3389/fnagi.2017.00282 PMID: 28890695

[33] Lue, L.F.; Rydel, R.; Brigham, E.F.; Yang, L.B.; Hampel, H.; Murphy, G.M., Jr; Brachova, L.; Yan, S.D.; Walker, D.G.; Shen, Y.; Rogers, J. Inflammatory repertoire of Alzheimer's disease and nondemented elderly microglia in vitro. Glia, 2001, 35(1), 72-79. http://dx.doi.org/10.1002/glia.1072 PMID: 11424194

[34] Walker, D.G.; Lue, L.F.; Beach, T.G. Gene expression profiling of amyloid beta peptide-stimulated human post-mortem brain microglia. Neurobiol. Aging, 2001, 22(6), 957-966. http://dx.doi.org/10.1016/S0197-4580(01)00306-2 PMID: 11755004

[35] Mietelska-Porowska, A.; Wojda, U. Lymphocytes ad inflammatory mediators in the interplay between brain and blood in Alzheimer's disease: Potential pools of new biomarker. J. Immunol. Res., 2017, 20174626540 http://dx.doi.org/10.1155/2017/4626540 PMID: 28293644

[36] Zhu, M.; Allard, J.S.; Zhang, Y.; Perez, E.; Spangler, E.L.; Becker, K.G.; Rapp, P.R. Age-related brain expression and regulation of the chemokine CCL4/MIP-1 $\beta$ in APP/PS1 double-transgenic mice. $J$. Neuropathol. Exp. Neurol., 2014, 73(4), 362-374. http://dx.doi.org/10.1097/NEN.0000000000000060 PMID: 24607962

[37] Rossner, S.; Lange-Dohna, C.; Zeitschel, U.; Perez-Polo, J.R. Alzheimer's disease beta-secretase BACE1 is not a neuron-specific enzyme. J. Neurochem., 2005, 92(2), 226-234. http://dx.doi.org/10.1111/j.1471-4159.2004.02857.x PMID: 15663471

[38] Lee, Y.K.; Kwak, D.H.; Oh, K.W.; Nam, S.Y.; Lee, B.J.; Yun, Y.W.; Kim, Y.B.; Han, S.B.; Hong, J.T. CCR5 deficiency induces astrocyte activation, Abeta deposit and impaired memory function. Neurobiol. Learn. Mem., 2009, 92(3), 356-363. http://dx.doi.org/10.1016/j.nlm.2009.04.003 PMID: 19394434

[39] Song, M.; Jin, J.; Lim, J.E.; Kou, J.; Pattanayak, A.; Rehman, J.A.; Kim, H.D.; Tahara, K.; Lalonde, R.; Fukuchi, K. TLR4 mutation reduces microglial activation, increases $\mathrm{A} \beta$ deposits and exacerbates cognitive deficits in a mouse model of Alzheimer's disease. $J$. Neuroinflammation, 2011, 8,92 .

http://dx.doi.org/10.1186/1742-2094-8-92 PMID: 21827663
[40] Bruno, V.; Copani, A.; Besong, G.; Scoto, G.; Nicoletti, F. Neuroprotective activity of chemokines against N-methyl-D-aspartate or betaamyloid-induced toxicity in culture. Eur. J. Pharmacol., 2000, 399(23), $117-121$

http://dx.doi.org/10.1016/S0014-2999(00)00367-8 PMID: 10884510

[41] Tripathy, D.; Thirumangalakudi, L.; Grammas, P. RANTES upregulation in the Alzheimer's disease brain: a possible neuroprotective role. Neurobiol. Aging, 2010, 31(1), 8-16.

http://dx.doi.org/10.1016/j.neurobiolaging.2008.03.009 PMID: 18440671

[42] Subramanian, S.; Ayala, P.; Wadsworth, T.L.; Harris, C.J.; Vandenbark, A.A.; Quinn, J.F.; Offner, H. CCR6: a biomarker for Alzheimer's-like disease in a triple transgenic mouse model. J. Alzheimers Dis., 2010, 22(2), 619-629. http://dx.doi.org/10.3233/JAD-2010-100852 PMID: 20847401

[43] Haskins, M.; Jones, T.E.; Lu, Q.; Bareiss, S.K. Early alterations in blood and brain RANTES and MCP-1 expression and the effect of exercise frequency in the $3 \times \mathrm{Tg}-\mathrm{AD}$ mouse model of Alzheimer's disease. Neurosci. Lett., 2016, 610, 165-170. http://dx.doi.org/10.1016/j.neulet.2015.11.002 PMID: 26547034

[44] Réaux-Le Goazigo, A.; Van Steenwinckel, J.; Rostène, W.; Mélik Parsadaniantz, S. Current status of chemokines in the adult CNS. Prog. Neurobiol., 2013, 104, 67-92.

http://dx.doi.org/10.1016/j.pneurobio.2013.02.001 PMID: 23454481

[45] Porcellini, E.; Ianni, M.; Carbone, I.; Franceschi, M.; Licastro, F. Monocyte chemoattractant protein-1 promoter polymorphism and plasma levels in alzheimer's disease. Immun. Ageing, 2013, 10(1), 6 . http://dx.doi.org/10.1186/1742-4933-10-6 PMID: 23432970

[46] Sokolova, A.; Hill, M.D.; Rahimi, F.; Warden, L.A.; Halliday, G.M.; Shepherd, C.E. Monocyte chemoattractant protein-1 plays a dominant role in the chronic inflammation observed in Alzheimer's disease. Brain Pathol., 2009, 19(3), 392-398. http://dx.doi.org/10.1111/j.1750-3639.2008.00188.x PMID: 18637012

[47] Vukic, V.; Callaghan, D.; Walker, D.; Lue, L.F.; Liu, Q.Y.; Couraud, P.O.; Romero, I.A.; Weksler, B.; Stanimirovic, D.B.; Zhang, W. Expression of inflammatory genes induced by beta-amyloid peptides in human brain endothelial cells and in Alzheimer's brain is mediated by the JNK-AP1 signaling pathway. Neurobiol. Dis., 2009, 34(1), 95-106. http://dx.doi.org/10.1016/j.nbd.2008.12.007 PMID: 19162185

[48] Grammas, P.; Ovase, R. Inflammatory factors are elevated in brain microvessels in Alzheimer's disease. Neurobiol. Aging, 2001, 22(6), $837-842$.

http://dx.doi.org/10.1016/S0197-4580(01)00276-7 PMID: 11754990

[49] Westin, K.; Buchhave, P.; Nielsen, H.; Minthon, L.; Janciauskiene, S.; Hansson, O. CCL2 is associated with a faster rate of cognitive decline during early stages of Alzheimer's disease., 2012.

http://dx.doi.org/10.1371/journal.pone.0030525

[50] Zhang, R.; Miller, R.G.; Madison, C.; Jin, X.; Honrada, R.; Harris, W.; Katz, J.; Forshew, D.A.; McGrath, M.S. Systemic immune system alterations in early stages of Alzheimer's disease. J. Neuroimmunol., 2013, 256(1-2), 38-42. http://dx.doi.org/10.1016/j.jneuroim.2013.01.002 PMID: 23380586

[51] Kimura, A.; Yoshikura, N.; Hayashi, Y.; Inuzuka, T. Cerebrospinal fluid C-C motif chemokine ligand 2 correlates with brain atrophy ad cognitive impairment in Alzheimer's disease. J. Alzheimers Dis., 2018, 61(2), 581-588. http://dx.doi.org/10.3233/JAD-170519 PMID: 29171996

[52] Lee, W.J.; Liao, Y.C.; Wang, Y.F.; Lin, I.F.; Wang, S.J.; Fuh, J.L. Plasma MCP-1 and cognitive decline in patients with Alzheimer's disease ad mild cognitive impairment: a Two year Follow-up Study. Sci. Rep., 2018, 8(1), 1280. http://dx.doi.org/10.1038/s41598-018-19807-y PMID: 29352259

[53] Yamamoto, M.; Horiba, M.; Buescher, J.L.; Huang, D.; Gendelman, H.E.; Ransohoff, R.M.; Ikezu, T. Overexpression of monocyte chemotactic protein-1/CCL2 in beta-amyloid precursor protein transgenic mice show accelerated diffuse beta-amyloid deposition. Am. J. Pathol., 2005, 166(5), 1475-1485. http://dx.doi.org/10.1016/S0002-9440(10)62364-4 PMID: 15855647

[54] El Khoury, J.; Toft, M.; Hickman, S.E.; Means, T.K.; Terada, K.; Geula, C.; Luster, A.D. Ccr2 deficiency impairs microglial accumulation and accelerates progression of Alzheimer-like disease. Nat. Med., 2007, 13(4), 432-438. http://dx.doi.org/10.1038/nm1555 PMID: 17351623 
[55] Xia, M.Q.; Bacskai, B.J.; Knowles, R.B.; Qin, S.X.; Hyman, B.T. Expression of the chemokine receptor CXCR3 on neurons and the elevated expression of its ligand IP-10 in reactive astrocytes: in vitro ERK1/2 activation and role in Alzheimer's disease. J. Neuroimmunol., 2000, $108(1-2), 227-235$ http://dx.doi.org/10.1016/S0165-5728(00)00285-X PMID: 10900358

[56] Naert, G.; Rivest, S. CC chemokine receptor 2 deficiency aggravates cognitive impairments and amyloid pathology in a transgenic mouse model of Alzheimer's disease. J. Neurosci., 2011, 31(16), 6208-6220. http://dx.doi.org/10.1523/JNEUROSCI.0299-11.2011 PMID: 21508244

[57] Zaheer, S.; Thangavel, R.; Wu, Y.; Khan, M.M.; Kempuraj, D.; Zaheer, A. Enhanced expression of glia maturation factor correlates with glial activation in the brain of triple transgenic Alzheimer's disease mice. Neurochem. Res., 2013, 38(1), 218-225. http://dx.doi.org/10.1007/s1 1064-012-0913-z PMID: 23086473

[58] Duan, R.S.; Yang, X.; Chen, Z.G.; Lu, M.O.; Morris, C.; Winblad, B.; Zhu, J. Decreased fractalkine and increased IP-10 expression in aged brain of APP(swe) transgenic mice. Neurochem. Res., 2008, 33(6), 1085-1089. http://dx.doi.org/10.1007/s11064-007-9554-z PMID: 18095157

[59] Galimberti, D.; Schoonenboom, N.; Scheltens, P.; Fenoglio, C.; Bouwman, F.; Venturelli, E.; Guidi, I.; Blankenstein, M.A.; Bresolin, N.; Scarpini, E. Intrathecal chemokine synthesis in mild cognitive impairment and Alzheimer disease. Arch. Neurol., 2006, 63(4), 538-543. http://dx.doi.org/10.1001/archneur.63.4.538 PMID: 16606766

[60] Ren, L.Q.; Gourmala, N.; Boddeke, H.W.; Gebicke-Haerter, P.J. Lipopolysaccharide-induced expression of IP-10 mRNA in rat brain and in cultured rat astrocytes and microglia. Brain Res. Mol. Brain Res., 1998, 59(2), 256-263. http://dx.doi.org/10.1016/S0169-328X(98)00170-3 PMID: 9729417

[61] Krauthausen, M.; Kummer, M.P.; Zimmermann, J.; Reyes-Irisarri, E.; Terwel, D.; Bulic, B.; Heneka, M.T.; Müller, M. CXCR3 promotes plaque formation and behavioral deficits in an Alzheimer's disease model. J. Clin. Invest., 2015, 125(1), 365-378. http://dx.doi.org/10.1172/JCI66771 PMID: 25500888

[62] Mizuno, T.; Kawanokuchi, J.; Numata, K.; Suzumura, A. Production and neuroprotective functions of fractalkine in the central nervous system. Brain Res., 2003, 979(1-2), 65-70. http://dx.doi.org/10.1016/S0006-8993(03)02867-1 PMID: 12850572

[63] Cardona, A.E.; Pioro, E.P.; Sasse, M.E.; Kostenko, V.; Cardona, S.M.; Dijkstra, I.M.; Huang, D.; Kidd, G.; Dombrowski, S.; Dutta, R.; Lee, J.C.; Cook, D.N.; Jung, S.; Lira, S.A.; Littman, D.R.; Ransohoff, R.M. Control of microglial neurotoxicity by the fractalkine receptor. Nat. Neurosci., 2006, 9(7), 917-924. http://dx.doi.org/10.1038/nn1715 PMID: 16732273

[64] Limatola, C.; Giovannelli, A.; Maggi, L.; Ragozzino, D.; Castellani, L.; Ciotti, M.T.; Vacca, F.; Mercanti, D.; Santoni, A.; Eusebi, F. SDF1alpha-mediated modulation of synaptic transmission in rat cerebellum. Eur. J. Neurosci., 2000, 12(7), 2497-2504. http://dx.doi.org/10.1046/j.1460-9568.2000.00139.x PMID: 10947825

[65] Kim, T.S.; Lim, H.K.; Lee, J.Y.; Kim, D.J.; Park, S.; Lee, C.; Lee, C.U. Changes in the levels of plasma soluble fractalkine in patients with mild cognitive impairment and Alzheimer's disease. Neurosci. Lett., 2008, 436(2), 196-200. http://dx.doi.org/10.1016/j.neulet.2008.03.019 PMID: 18378084

[66] Strobel, S.; Grünblatt, E.; Riederer, P.; Heinsen, H.; Arzberger, T.; AlSarraj, S.; Troakes, C.; Ferrer, I.; Monoranu, C.M. Changes in the expression of genes related to neuroinflammation over the course of sporadic Alzheimer's disease progression: CX3CL1, TREM2, and PPAR $\gamma . J$. Neural Transm. (Vienna), 2015, 122(7), 1069-1076. http://dx.doi.org/10.1007/s00702-015-1369-5 PMID: 25596843

[67] Lee, S.; Varvel, N.H.; Konerth, M.E.; Xu, G.; Cardona, A.E.; Ransohoff, R.M.; Lamb, B.T. CX3CR1 deficiency alters microglial activation and reduces beta-amyloid deposition in two Alzheimer's disease mouse models. Am. J. Pathol., 2010, 177(5), 2549-2562. http://dx.doi.org/10.2353/ajpath.2010.100265 PMID: 20864679

[68] Wu, J.; Bie, B.; Yang, H.; Xu, J.J.; Brown, D.L.; Naguib, M. Suppression of central chemokine fractalkine receptor signaling alleviates amyloid-induced memory deficiency. Neurobiol. Aging, 2013, 34(12), 2843-2852. http://dx.doi.org/10.1016/j.neurobiolaging.2013.06.003 PMID: 23855980

[69] Cho, S.H.; Sun, B.; Zhou, Y.; Kauppinen, T.M.; Halabisky, B.; Wes, P.; Ransohoff, R.M.; Gan, L. CX3CR1 protein signaling modulates microglial activation and protects against plaque-independent cognitive deficits in a mouse model of Alzheimer disease. J. Biol. Chem., 2011, 286(37), 32713-32722.

http://dx.doi.org/10.1074/jbc.M111.254268 PMID: 21771791

[70] Ashutosh, K.; Kou, W.; Cotter, R.; Borgmann, K.; Wu, L.; Persidsky, R.; Sakhuja, N.; Ghorpade, A. CXCL8 protects human neurons from amyloid- $\beta$-induced neurotoxicity: relevance to Alzheimer's disease. Biochem. Biophys. Res. Commun., 2011, 412(4), 565-571. http://dx.doi.org/10.1016/j.bbrc.2011.07.127 PMID: 21840299

[71] Alsadany, M.A.; Shehata, H.H.; Mohamad, M.I.; Mahfouz, R.G. Histone deacetylases enzyme, copper, and IL-8 levels in patients with Alzheimer's disease. Am. J. Alzheimers Dis. Other Demen., 2013, 28(1), 54-61.

http://dx.doi.org/10.1177/1533317512467680 PMID: 23242124

[72] Xiong, H.; Boyle, J.; Winkelbauer, M.; Gorantla, S.; Zheng, J.; Ghorpade, A.; Persidsky, Y.; Carlson, K.A.; Gendelman, H.E. Inhibition of long-term potentiation by interleukin-8: implications for human immunodeficiency virus-1-associated dementia. J. Neurosci. Res., 2003, 71(4), 600-607.

http://dx.doi.org/10.1002/jnr.10503 PMID: 12548717

[73] Flynn, G.; Maru, S.; Loughlin, J.; Romero, I.A.; Male, D. Regulation of chemokine receptor expression in human microglia and astrocytes. J. Neuroimmunol., 2003, 136(1-2), 84-93. http://dx.doi.org/10.1016/S0165-5728(03)00009-2 PMID: 12620646

[74] Bakshi, P.; Margenthaler, E.; Reed, J.; Crawford, F.; Mullan, M. Depletion of CXCR2 inhibits $\gamma$-secretase activity and amyloid- $\beta$ production in a murine model of Alzheimer's disease. Cytokine, 2011, 53(2), 163-169. http://dx.doi.org/10.1016/j.cyto.2010.10.008 PMID: 21084199

[75] Liu, Y.J.; Guo, D.W.; Tian, L.; Shang, D.S.; Zhao, W.D.; Li, B.; Fang, W.G.; Zhu, L.; Chen, Y.H. Peripheral T cells derived from Alzheimer's disease patients overexpress CXCR2 contributing to its transendothelial migration, which is microglial TNF-alpha-dependent. Neurobiol. Aging, 2010, 31(2), 175-188.

http://dx.doi.org/10.1016/j.neurobiolaging.2008.03.024 PMID: 18462836

[76] Schönemeier, B.; Kolodziej, A.; Schulz, S.; Jacobs, S.; Hoellt, V.; Stumm, R. Regional and cellular localization of the CXC112/SDF-1 chemokine receptor CXCR7 in the developing and adult rat brain. $J$. Comp. Neurol., 2008, 510(2), 207-220.

http://dx.doi.org/10.1002/cne.21780 PMID: 18615560

[77] Laske, C.; Stellos, K.; Eschweiler, G.W.; Leyhe, T.; Gawaz, M. Decreased CXCL12 (SDF-1) plasma levels in early Alzheimer's disease: a contribution to a deficient hematopoietic brain support? J. Alzheimers Dis., 2008, 15(1), 83-95. http://dx.doi.org/10.3233/JAD-2008-15107 PMID: 18780969

[78] Parachikova, A.; Cotman, C.W. Reduced CXCL12/CXCR4 results in impaired learning and is downregulated in a mouse model of Alzheimer disease. Neurobiol. Dis., 2007, 28(2), 143-153. http://dx.doi.org/10.1016/j.nbd.2007.07.001 PMID: 17764962

[79] Parachikova, A.; Nichol, K.E.; Cotman, C.W. Short-term exercise in aged $\mathrm{Tg} 2576$ mice alters neuroinflammation and improves cognition. Neurobiol. Dis., 2008, 30(1), 121-129. http://dx.doi.org/10.1016/j.nbd.2007.12.008 PMID: 18258444

[80] Lu, M.; Grove, E.A.; Miller, R.J. Abnormal development of the hippocampal dentate gyrus in mice lacking the CXCR4 chemokine receptor. Proc. Natl. Acad. Sci. USA, 2002, 99(10), 7090-7095. http://dx.doi.org/10.1073/pnas.092013799 PMID: 11983855

[81] Raman, D.; Milatovic, S.Z.; Milatovic, D.; Splittgerber, R.; Fan, G.H.; Richmond, A. Chemokines, macrophage inflammatory protein-2 and stromal cell-derived factor-1 $\alpha$, suppress amyloid $\beta$-induced neurotoxicity. Toxicol. Appl. Pharmacol., 2011, 256(3), 300-313. http://dx.doi.org/10.1016/j.taap.2011.06.006 PMID: 21704645

[82] Capsoni, S.; Malerba, F.; Carucci, N.M.; Rizzi, C.; Criscuolo, C.; Origlia, N.; Calvello, M.; Viegi, A.; Meli, G.; Cattaneo, A. The chemokine CXCL12 mediates the anti-amyloidogenic action of painless human nerve growth factor. Brain, 2017, 140(1), 201-217. http://dx.doi.org/10.1093/brain/aww271 PMID: 28031222 